Este artículo estudia la traducción fraseológica considerada ARTICULOS · 117-138 como uno de los escollos desafiantes para los traductores. El error que el traductor comete en cualquiera de las fases del proceso traslativo, desde la identificación de la unidad fraseológica y la interpretación de la misma, hasta la búsqueda de equivalentes en la lengua meta y el establecimiento de correspondencias en el texto de llegada, puede producir un sentido totalmente diferente del presentado en el texto de origen. En este estudio se analiza la traducción de paremias y locuciones en las tres versiones árabes del Lazarillo de Tormes, prestando especial atención a las técnicas de traducción manejadas por los traductores.

Palabras Clave: traducción, fraseología, Lazarillo de Tormes, árabe, paremias, locuciones.

\title{
El Lazarillo de Tormes en árabe: la traducción de paremias y locuciones
}

Yasmeen Mahmoud Ahmed MAHMOUD

Universidad de Ain Shams, El Cairo

\section{Lazarillo de Tormes in Arabic: Translation of proverbs and idioms}

This paper studies the phraseological trans/ation considered as one of the challenging pitfalls for translators. The error that the translator commits in any of the phases of the translational process, from the identification of the phraseological unit and the interpretation of it, to the search of equivalents in the target language and the establishment of correspondences in the target text, can produce a meaning that is different than the one presented in the source text. This study analyzes the translation of proverbs and idioms in the three Arabic versions of Lazarillo de Tormes, focusing on the translation techniques managed by the translators.

KEY WORDS: translation, phraseology, Lazarillo de Tormes, Arabic, proverbs, idioms. 


\section{INTRODUCCIÓN ${ }^{\mathrm{I}}$}

Las estructuras lingüísticas fijas, frecuentemente empleadas tanto en el lenguaje hablado como en el escrito, forman un componente vivo de suma importancia en el sistema lingüístico de cualquier sociedad. No obstante, su transferencia de una lengua a otra constituye un escollo desafiante para los traductores, cuya tarea empieza con el reconocimiento e identificación de la unidad fraseológica, pasa por la interpretación de la misma, y termina con su transferencia a la lengua meta, fase en que se agudiza la dificultad y aumentan las posibilidades de caer en errores.

El excesivo uso de unidades fraseológicas (UFs) en el Lazarillo de Tormes nos ha incitado a analizar las traducciones al árabe de esta obra que representa una cierta clase social en una zona geográfica y una época determinadas, en este caso, la muy baja clase social de la Castilla del siglo XVI.

Nuestro trabajo se basa en un análisis comparativo entre el To y sus tres traducciones, por una parte, y entre las mismas traducciones, por otra, atendiendo única y exclusivamente a la fase de reexpresión de las locuciones y paremias que, por más que intensifiquen la expresividad del diálogo, hacen más difícil la tarea del traductor. Tomamos los equivalentes propuestos en dichas traducciones como punto de partida para la indagación de las técnicas de traducción empleadas en cada caso.

Excepto en los casos de equivalencia nula, ofrecemos traducciones alternativas de carácter fraseológico, que de ningún modo presentamos como las únicas versiones válidas, sino como propuestas de traducción.

Cabe señalar que algunos de los ejemplos sacados de las versiones árabes que iremos

I Para la transcripción de la palabras árabes seguimos el sistema de Javier Bezos (2005). [http://www.tex-tipografia.com/archive/TransArabe.pdf] citando en este estudio contienen errores de diversa índole, pero, por razones de espacio y por la especificidad del análisis, el comentario de estos errores no tendrá cabida en el presente artículo.

\section{EL LAZARILLO DE TORMES \\ Y EL MUNDO ÁRABE}

La influencia árabe en la literatura española ha sido, y sigue siendo, el objeto de muchos trabajos, tanto de hispanistas árabes como de arabistas españoles. Investigadores e historiadores modernos como Juan Vernet (I923-20II), Emilio García Gómez (I905-I995), Federico Corriente (I940-) y Mahmoud Ali Makki (I929-) han sido capaces de detectar un gran número de influencias árabes en la poesía y la prosa españolas.

El ámbito paremiológico no quedó lejos de los estudios de los mencionados autores, así que las posibles influencias árabes en el refranero español han sido justificadas por García Gómez (1977: 376), quien opina que refranes del Oriente Extremo, India, Persia y la Grecia Romana han pasado al refranero árabe oriental antes de pasar al refranero arábigo-andaluz y de éste al español.

El tema de la influencia árabe en el Lazarillo ha sido durante décadas el eje de diversos estudios. En argumentos a favor y en otros en contra abundan muchos trabajos como el de Francisco Ayala (1965), quien llama la atención a un cuentecillo árabe que, según él, sirve de base del episodio de «la casa lóbrega y oscura, donde nunca comen ni beben» incluido en el tratado III $^{2}$. La misma opinión ha sido plenamente

2 Se trata de una anécdota citada en el libro de Ibrāhīm al-Bayhaqī titulado Al-mahāàsin wa-l-masāwi' [Las ventajas y las desventajas], que fue escrito antes del año 932, fecha en que fue asesinado el autor; $y$ en el 
sustentada por Alberto del Monte (1971) y minuciosamente estudiada por Fernando de la Granja (1971).

Como opina Ğamīl Ḥamdāwī (Ğabrūnī y Masārī, 2007: II y I2), la literatura picaresca apareció en España influida por la literatura arábigo-andaluza que surgió con la aparición de una clase social de pícaros árabes marginados tanto en España como en otras partes del mundo árabe. La misma postura adopta 'Abd al-Hādī Sa dūn (20or: 9) quien defiende además la influencia de las maqamas árabes (como las maqamas de Al-Hamadān̄ī y Al-Ḥarīīi) en el Lazarillo.

No obstante, no faltan quienes presentan otro planteamiento totalmente opuesto, como Ángel Flores, quien, según menciona Ğamīl Ḥamdāwī (Ğabrūnī y Masārī, 2007: I4), niega la posibilidad de que el Lazarillo hubiera sido influido por el protagonista pícaro de las maqamas de Al-Harīīī, por una parte, porque estas últimas no tienen la estructura autobiográfica del Lazarillo, excepto una sola maqama, y, por otra parte, porque las maqamas árabes se escribían para un público de cierto grado de conocimiento lingüístico, hecho que dificultó su traducción tanto al latín como al español.

La opinión de Flores ha sido apoyada por otros como al-Outmānī (2007), quien ve que «la literatura árabe, tanto la andalusí como la oriental, no tuvo ningún papel de relieve respecto a la picaresca literaria española».

El Lazarillo de Tormes ha sido hasta la fecha traducido al árabe en tres ocasiones, a saber: la traducción del egipcio 'Abd al-Raḥmān Badawī (I979), la del iraquí 'Abd al-Hādī Sa dūn (200I) y la de los marroquíes Idrīs al-Ğabrūnī

libro llamado $A l-A \bar{g} \bar{a} n \bar{\imath}$ [Las canciones] de Abū Farağ al-Așfahānī que murió en el año 966. Aparece también en libros de autores andaluces como Hadä' iq al-Azāabir [Los jardines de flores] de Ibn 'Āṣim al-Andalusī (I358-I425). y Muḥammad al-Masārī (2007) ${ }^{3}$. Nos resulta importante señalar que esta última versión no es más que una copia de la traducción de Badawī (I979). Su única parte original es la introducción muy valiosa realizada por el crítico marroquí Gamīl Ḥamdāwī. El esfuerzo que Ğabrūnī y Masārī han hecho consiste solamente en la redivisión de los párrafos de la versión de Badawī, además de hacer unas leves modificaciones que hemos elegido subrayar en los ejemplos analizados, ya que, en algunos casos, dichas variaciones se producen en partes del texto que contienen fraseologismos y paremias.

\section{LA TRADUCCIÓN DE FRASEOLOGISMOS Y PAREMIAS}

Para la definición del término de unidades fraseológicas, considerado como un «término genérico» (Penadés, 199: 13) que abarca todo el conjunto de locuciones, frases hechas, frases proverbiales, modismos, refranes, expresiones idiomáticas, expresiones fijas, colocaciones, etc. (Ruiz Gurillo, I998: I2), nos basamos en la propuesta de Corpas Pastor (1996: 20), para quien las unidades fraseológicas son:

[...] unidades léxicas formadas por más de dos palabras gráficas en su límite inferior, cuyo nivel superior se sitúa en el nivel de la oración compuesta. Dichas unidades se caracterizan por su alta frecuencia de uso, y de coaparición de sus elementos integrantes; por su institucionalización, entendida en términos de fijación y especialización semántica; por su idiomaticidad y variación potenciales; así como por el grado en el cual se dan todos estos aspectos en los distintos tipos.

3 En I987 la editorial iraquí llamada «Dār Taqafat al-Aț̣āl al- 'Irāqiyya» publicó una traducción en árabe moderno, realizada por Marwān Ibrāhīm y basada en una adaptación resumida del Lazarillo.

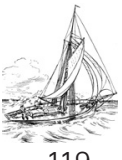

119 
Como es bien sabido, la elección de las técnicas empleadas en la traducción de un texto dado se realiza conforme a las circunstancias lingüísticas y a los planos de significación actualizados en el contexto. Cuando se trata de la traslación de expresiones idiomáticas de una lengua a otra, se supone una gran complejidad, ya que a la dificultad común y corriente relacionada con la determinación de la técnica más adecuada para la traducción se suman otras dificultades relativas a la identificación de la estructura fraseológica, la interpretación de su carga semántico-discursiva y la búsqueda de equivalentes literales o conceptuales en la lengua/cultura meta. En este aspecto dice Mona Baker (1992: 65):

The main problems that idiomatic and fixed expressions pose in translation relate to two main areas: the ability to recognize and interpret an idiom correctly; and the difficulties involved in rendering the various aspects of meaning that an idiom or a fixed expression conveys into the target language. These difficulties are much more pronounced in the case of idioms than they are in the case of fixed expressions.

En el terreno de la traducción fraseológica siempre hay dificultades, las cuales agrupa Sevilla Muñoz (I997: 43I-435) en tres tipos: terminológicas y conceptuales; gramaticales y semánticas; y lexicográficas y paremiográficas. Para la traducción de UFS, Corpas Pastor (2003: 28I) distingue cuatro pasos esenciales: la identificación de la UF, la interpretación de la misma, la búsqueda de correspondencias en el plano léxico y el establecimiento de correspondencias en el plano textual.

Para la traducción paremiológica, Julia Sevilla Muñoz (20II) y Julia y Manuel Sevilla (2000, 2004a, 2004b, 2005a, 2005b y 2005c) proponen cuatro técnicas: la actancial (buscar correspondencias con el mismo actante ${ }^{4}$ o con un actante similar); la temática (buscar correspondencias a través de la idea clave); la sinonímica (buscar correspondencias literales y/o conceptuales teniendo en cuenta el grado de equivalencia de significado de las paremias que poseen la misma idea clave); y la hiperonímica (recurrir al hiperónimo, al vocablo genérico cuando no se localiza el específico). Estas técnicas son, al menos hasta la fecha, las más válidas para la traducción de refranes, y en muchos casos son de gran uso también para la traducción de otros tipos de fraseologismos, sobre todo las locuciones.

Para la traducción de locuciones, englobadas en su mayoría entre las denominadas por $\mathrm{New}^{-}$ mark (1995: 152) «metáforas estereotipadas», se han postulado algunos métodos cuya aplicación depende del grado de equivalencia denotativa y connotativa entre las UFs de las dos lenguas del proceso traductor. Así, considerando que la metáfora es traducible pero con un grado, aunque sea mínimo, de inequivalencia interlingüística, Newmark ofrece tres procedimientos para la traducción de la misma. El primero se basa en «reproducir la misma imagen en la LT [lengua terminal], si su frecuencia de uso y su curso son parecidos en el registro apropiado en la LT» (Newmark, 1995: 153), método que corresponde al propuesto por Corpas Pastor (2003: 206) para la traducción de una UF por otra en la lengua meta (LM) que mantenga con ella una equivalencia total. El segundo procedimiento consiste en «reemplazar la imagen de la LO por otra imagen en la LT ya reconocida» que, aunque difiera denotativamente, guarde la misma función y el mismo efecto comunicativo (Newmark, 1995: I53). Esta técnica traductiva es análoga a la téc

4 Según los dos autores se entiende por actante «el sustantivo que designa el ser o el objeto que participa en el proceso expresado por el verbo». 
nica de «sustitución», mediante la cual, según Corpas Pastor (2003: 207), se pueden traducir las unidades fraseológicas que tienen en la LM correspondencias que encierran diferencias parciales pero "presentan el mismo valor funcional y son comunicativamente equivalentes». Este procedimiento corresponde también con la llamada por Julia y Manuel Sevilla Muñoz (2004b) «técnica temática». Para la imagen que no tiene equivalencia literal ni funcional en la lengua meta Newmark (1995: 155) dedica el tercer procedimiento consistente en limitarse única y exclusivamente a reproducir el sentido de la imagen en cuestión. Es el mismo caso en que Corpas Pastor (2003: 208) recomienda recurrir a la "paráfrasis», aunque Sevilla Muñoz (20II) opta en tal ocasión por la técnica hiperonímica que «podría sacar al traductor de más de un apuro».

\section{LA TRADUCCIÓN AL ÁRABE DE}

\section{PAREMIAS Y LOCUCIONES CONTENIDAS}

\section{EN EL LAZARILLO DE TORMES}

De acuerdo con los grados de equivalencia establecida entre las UFS de la lengua española y las pertenecientes a la lengua árabe, varían los procedimientos y técnicas empleados por los traductores del Lazarillo. En esta parte nos centraremos en la cuarta fase de la traducción fraseológica, o sea, la del establecimiento de correspondencias en el plano textual. Ocupándonos de la traducción como proceso, analizamos los procedimientos empleados para traducir al árabe las unidades fraseológicas presentes en el Lazarillo. Nos limitamos a estudiar las paremias y locuciones en especial por los muchos puntos que tienen en común, y porque son las UFS más presentes en gran medida en la obra en cuestión.

\section{I. La traducción de paremias}

La traslación al árabe de las paremias del Lazarillo ha sido realizada por lo general en las tres versiones mediante una traducción literal, lo que provoca una fuerte pérdida expresiva. $\mathrm{He}$ aquí un ejemplo:

[...] y a mi madre pusieron pena por justicia, sobre el acostumbrado centenario, que en casa del sobredicho comendador no entrase ni al lastimado Zaide en la suya acogiese. Por no echar la soga tras el caldero, la triste se esforzó y cumplió la sentencia. (Francisco Rico, 2000, a partir de ahora Rico: 20)

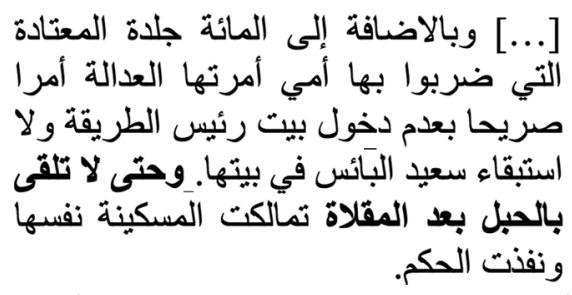

(Badawī, I979, a partir de ahora Bad.: 4I)

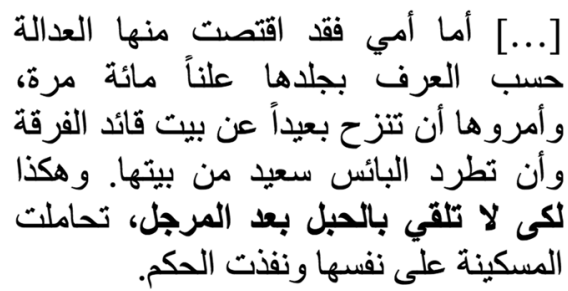

(Sa 'dūn, 200I, a partir de ahora Sa 'd.: I7)

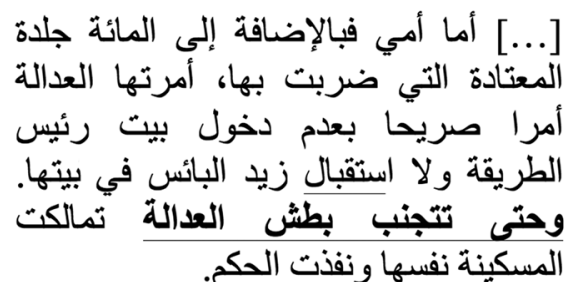

(Ğabrūnī y Masārīi, 2007, a partir de ahora Ğab. y Mas.: 25)

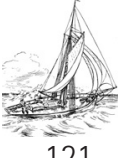

121 
«Dejar perder lo accesorio una vez perdido lo principal» (Sbarbi, I89I, II: 36I) y «es tras lo perdido, soltar el instrumento y remedio con que se ha de cobrar, y echar lo menos tras lo más» (Correas, I627=I906: I4I) explican el sentido connotativo de la paremia española Echar la soga tras el caldero. Lo que literalmente denota este refrán es que cuando a una persona se le cae el caldero en el pozo, ésta tiene que echar la soga con la que estaba atado el caldero porque no le servirá de nada. En este pasaje del Lazarillo, contextualizando la paremia, que aparece en forma negativa, vemos que está indicando lo contrario, es decir, mantener y no estropear lo accesorio aunque sea menos importante que lo ya perdido. La paremia se emplea para referirse al estado de la madre de Lázaro que, tras haber sido castigada y privada tanto de entrar en la casa del Comendador como de acoger en su misma casa a su marido, padrastro de Lázaro, se vio obligada a cumplir la condena para no perderlo todo ni causar más problemas.

Los dos primeros traductores, aunque identifican la paremia del то, no la reproducen mediante una correspondencia fraseológica árabe y parecen haber querido respetar en cierta medida el habla característica del protagonista. No obstante, mediante una nota final en el primer caso, y otra a pie de página en el segundo, ambos aluden al carácter paremiológico de la unidad lingüística española y explican la connotación que supone el uso de la misma.

Uno de los muy pocos casos en que la versión de Ğabrūnī y Masārī difiere de la de Badawī es el de la traducción de esta paremia. Parece que a los dos traductores marroquíes no les resultó conveniente la literalidad de la traducción de Badawī y optaron por una traducción pragmática de la UF. Su traducción, que literalmente significa "para evitar la tiranía de la justicia», va más allá del significado denotativo de la pare mia, y a la vez pierde expresividad.
Nuestra búsqueda de posibles equivalentes árabes nos ha llevado a un refrán clásico que, a nuestro juicio, hubiera sido una mejor elección. La paremia a la que nos referimos,

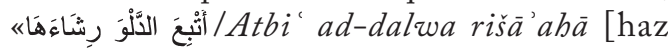
seguir la cuerda al pozal]» (Bakrī, 1971: 346) se emplea para aconsejar a quien gasta, ofrece o pierde lo más, que no mantenga lo menos. El refrán propuesto comparte con la paremia española el mismo concepto (no aferrarse a lo accesorio cuando no tienes lo principal) y los mismos actantes (la cuerda y el cubo).

Por tratarse de dos lenguas pertenecientes a familias lingüísticas distintas, es lógico presumir que no son muchos, aunque sí existen algunos, los casos de plena equivalencia fraseológica, que se produce cuando la unidad fraseológica original (UFO) y su correspondiente en la LM presentan «el mismo significado denotativo y connotativo, una misma fase metafórica, una misma distribución y frecuencia de uso, las mismas implicaturas convencionales, la misma carga pragmática y similares connotaciones (restricciones diastráticas, difásicas y diatópicas)» (Corpas Pastor, 2003: 28I-282). Así que, en el caso que nos atañe, a pesar de la coincidencia literal y conceptual entre la UFO y la equivalente árabe que proponemos, es interesante subrayar que mientras el vocablo «cuerda» en la paremia española es un término genérico que, según el Diccionario de la Real Academia Española (DRAE), se refiere al «conjunto de hilos de lino, cáñamo, cerda u otra materia semejante, que torcidos forman un solo cuerpo más o menos grueso, largo y flexible [que] sirve para atar, suspender pesos,

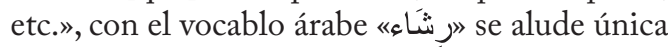

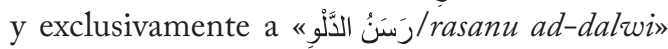
(Ibn Manz̄ūr, 630-7II=I999, V: 223) que es «la cuerda del pozal».

Dicha especificación del vocablo árabe "ارشَاءع, que reproduce la misma carga semán- 
tica del actante de la UFO, ayuda a los lectores del TM a capturar el sentido de la paremia árabe, cosa que no ocurre con los dos vocablos empleados por Badawī y Sa'dūn en sus respec-

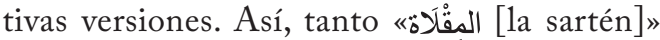
como "المَرْجَل [el caldero]» son instrumentos de cocina cuyo uso en este contexto puede perturbar al lector árabe.

Otra traducción literal se manifiesta en el siguiente ejemplo:

Finalmente, el clérigo me rescibió por suyo. Escapé del trueno y di en el relámpago, porque era el ciego para con éste un Alejandro Magno. (Rico: 47)

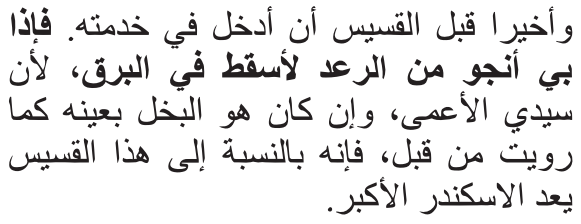

(Bad.: 55)

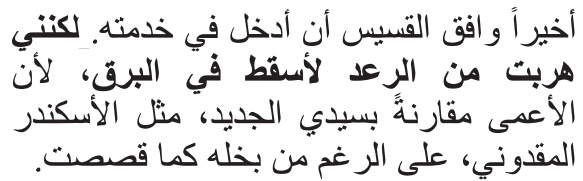

(Sa'd.: 31)

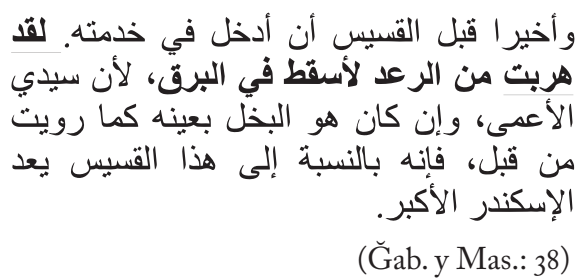

Como muestra el ejemplo, los traductores recurren a la literalidad aunque sí existe más de una paremia árabe que, insertada en el contexto, habrían dado un resultado más expresivo. La idea de «a veces, por tratar de evitar un problema, se desemboca en una situación más difícil todavía» (Sevilla Muñoz y Ruiz-
Ayúcar, 2009) la expresan muchas paremias árabes clásicas, aunque con actantes diferentes. Valga como ilustración el refrán clásico

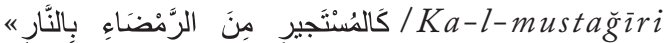
min ar-ramd̄a ${ }^{\prime} i$ bi-n-nāri [como quien se refugia del suelo caldeado yendo al fuego] que goza de una amplia circulación en el habla árabe culta. Dicha paremia se emplea para describir a quien escapa de una adversidad (el suelo caldeado) y cae en otra más grave (el fuego), lo que aumenta su dolor (Ṣinīe et ál., I992: 20).

Otra posible correspondencia conceptual

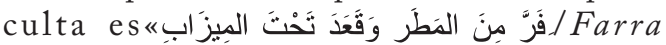
min al-mațari wa ka'ada taht al-mizābìn, que literalmente quiere decir «huyó de la lluvia y se sentó debajo del desaguadero» (Maydānī, I838I843=I955: 90).

En el ejemplo que sigue la frase proverbial ha sido traducida literalmente por una misma frase en las tres versiones árabes:

Porque una mañana, levantándose el triste en camisa, subió a lo alto de la casa a hacer sus menesteres, y en tanto yo, por salir de sospecha, desenvolvíle el jubón y las calzas, que a la cabecera dejó, y hallé una bolsilla de terciopelo raso, hecho cien dobleces y sin maldita la blanca ni señal que la hubiese tenido mucho tiempo. «Éste —decía yo- es pobre, y nadie da lo que no tiene; [...]». (Rico: 9I)

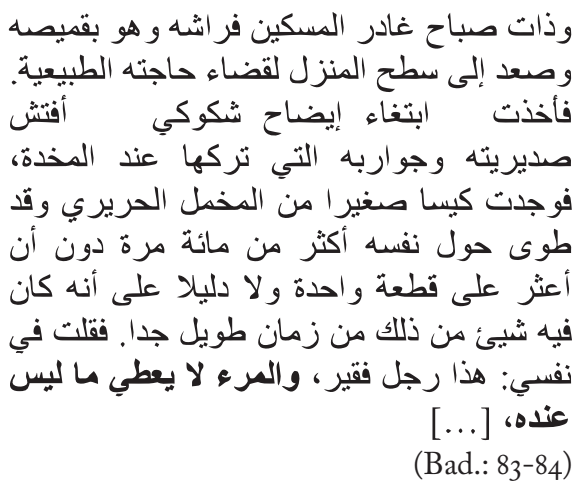

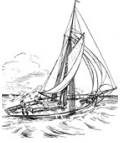

123 
صباح ما، نهض البائس وصعد سطح الدار

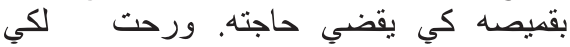

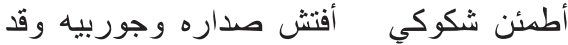

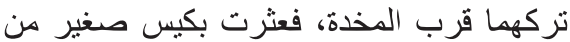
القطيفة الحائلة وقد طو اه أكثر من مائة مرة دون دون

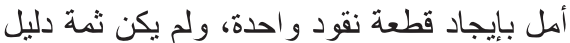

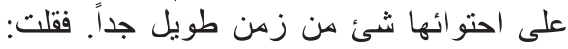

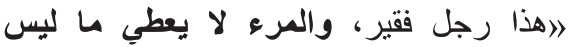

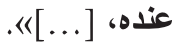

(Sa d.: 57)

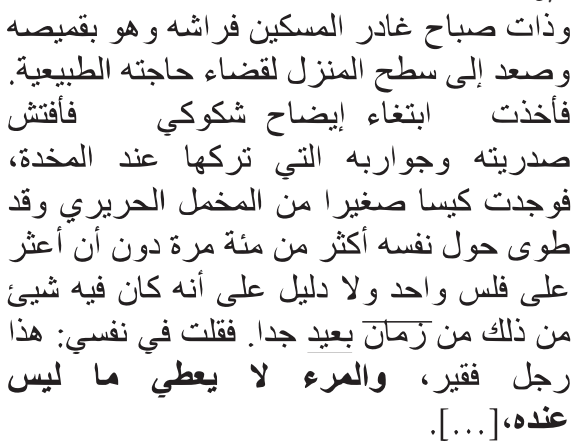

(Ğab. y Mas.: 64)

A pesar de que la traducción literal de una UF no suele dar resultados satisfactorios y resta expresividad al diálogo, en lo que concierne a este caso, el sentido de la frase árabe se entiende perfectamente. Sin embargo, hay una frase proverbial árabe muy célebre que hubiera despertado en el lector árabe las mismas reflexiones que la Ufo provoca en los lectores nativos. Nos

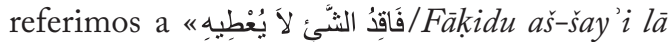
yu țīhi [Quien no tiene una cosa, no la puede dar]», que aunque no concuerda literalmente con la paremia española, sí comparte con ella el mismo concepto y la misma idea.

En algunas ocasiones el autor del Lazarillo recurre a la modificación fraseológica presentando la paremia con algunas alteraciones respecto a su forma genérica registrada en los repertorios paremiográficos. Valga como ejem- plo el proverbio célebre La necesidad hace maestros (Correas, I627=I906: I70) que, a su vez, tiene diferentes variantes en el habla española, como La necesidad suele ser maestra, o hace maestro y La necesidad es grande maestra de invenciones (Sbarbi, I89I, II: I3I). En la obra en cuestión, la paremia La necesidad [es] tan gran maestra (Rico: 62) sufre una modificación producida por la combinación de elementos diferentes sacados de más de una variante:

Como la necesidad sea tan gran maestra, viéndome con tanta siempre, noche y día estaba pensando la manera que tendría en sustentar el vivir. (Rico: 6I-62)

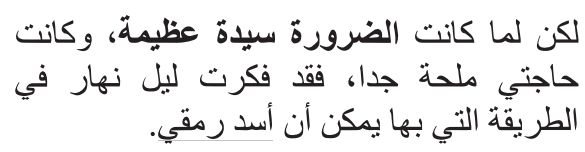

(Bad.: 63)

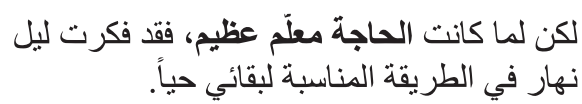

(Sa'd.: 38-39)

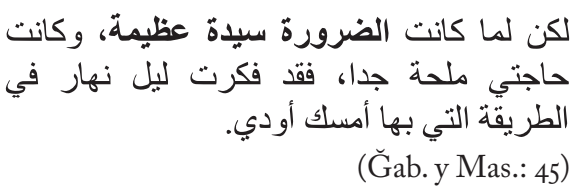

Describiendo su estado con su segundo amo, dice Lázaro que éste, el clérigo, era avaro y no le alimentaba convenientemente hasta que llegó el momento en que Lázaro se cansó y su necesidad le llevó a robarle al clérigo tras haber sacado una copia de la llave del baúl donde escondía el pan. Insertada en este contexto, la frase proverbial añade un matiz expresivo al contenido semántico que se resume en que «cuando falta lo necesario para el sustento, o la precisión del riesgo, hace que ejecute uno a la fuerza con habilidad y destreza, lo que parece que no se sabía, o no se había aprendido» (Sbarbi, I89I, II: I3I). 
En ninguna de las versiones árabes se da una traducción fraseológica de esta unidad lingüística estable, sino que, en cambio, Sa dūn ha optado por una traducción literal que es parcialmente errónea, mientras Badawī ha presentado una traducción totalmente falsificada, que automáticamente ha sido plagiada en la versión de Ğabrūnī y Masārī.

En la primera versión árabe, el traductor confunde la necesidad con el sentido de indigencia, escasez, carencia y pobreza, que es el significado intencionado por el autor del Lazarillo, y la otra necesidad que se refiere a la exigencia, la urgencia y el apuro. Badawī reproduce el segundo sentido - el no intencionado por el autor- mediante su equivalente árabe contenido en la palabra

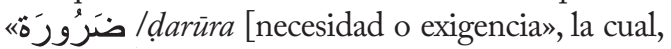

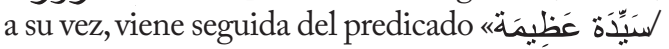
sayyida 'azima [una gran mujer]", produciendo un error semántico y expresivo, y alejando al lector árabe de la intención del autor del To.

En cuanto a la versión de Sa'dūn, se nota que el traductor captura el sentido intencionado del vocablo necesidad y lo traduce por "لحَاحَالحal-hāğa», una palabra árabe que reproduce los sentidos de indigencia, carencia y escasez. No obstante, traduce «una gran maestra» por su forma masculina "مُعَلِّم عَظِيم/mu'allim 'ażìm [un gran maestro]». La literalidad que Sa dūn elige como estrategia de traducción de la paremia española, cuyo carácter fraseológico sospechamos que hubiera sido identificado por el traductor, reproduce el sentido denotativo del proverbio, aunque con una pérdida estilística.

En árabe empleamos ampliamente una paremia clásica que representa la misma idea y el mismo concepto que la paremia española, además de poseer una base metafórica. Nos refe-

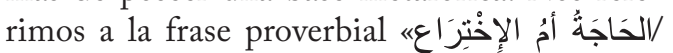
Al-hāğatu umu al-ihtirā 'i» que literalmente significa «la necesidad es madre de la invención».
Otra posible solución es la paremia clásica

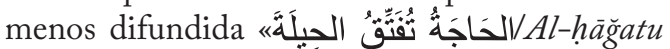
tufattiku al-hīlata [la necesidad descose el truco]» que, según el Diccionario contextual de expresiones fraseológicas ${ }^{5}$ (DCEF) de Șīnī (I996), da a entender que siempre que el hombre necesite algo, busca y piensa hasta llegar a una idea o invención que satisfaga su necesidad.

\subsection{La traducción de locuciones}

El hecho de que la locución es una «combinación estable de dos o más términos, que funciona como elemento oracional y cuyo sentido unitario consabido no se justifica, sin más, como una suma del significado normal de los componentes» (Casares, I950=I992: I70) hace que el traductor a veces se confunda y la traduzca tal como hace con cualquier otro enunciado en el discurso.

En las versiones árabes del Lazarillo se notan casos en que el traductor no reconoce la locución; otros en que sí la identifica pero falla en entender correctamente su sentido; y otros últimos casos en que el traductor identifica la locución y correctamente la interpreta, pero la traduce literalmente o por un equivalente fraseológico inadecuado. A continuación presentamos dichos casos que hemos dividido conforme a las técnicas de traducción fraseológica empleadas.

\subsection{Traducción mediante un fraseologismo (sustitución)}

A pesar de las inequivalencias translingüísticas debidas a las peculiaridades culturales plasmadas en cada lengua, sí existen casos de equivalencias fraseológicas tanto conceptuales como literales y conceptuales a la vez. Esto se

5 Es nuestra traducción del título árabe الهعجم السياقي للتعبير ات الاصطلاحية $/$ /Al-mu' '̆am alsìyākị li-l-ta 'bìrāt al-iștilăhiniyya.

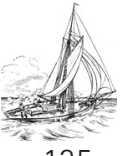

125 
manifiesta en algunas locuciones del To que han sido traducidas por equivalentes fraseológicos. El primer ejemplo aparece en el tratado II, que cuenta la vida de Lázaro con el avaro clérigo quien lo mataba de hambre. Lázaro tuvo que robarle el pan guardado en el baúl culpando a los ratones. La locución verbal darse al diablo ha sido empleada para expresar la reacción del clérigo cuando se dio cuenta de la desaparición del pan sin que cayera el ratón que suponía que lo comía:

Como hallase el pan ratonado y el queso comido y no cayese el ratón que lo comía, dábase al diablo. (Rico: 65 )

$$
\begin{aligned}
& \text { فلما شاهد القسيس أن الخبز يقرض، والجبن يؤكل، دون }
\end{aligned}
$$

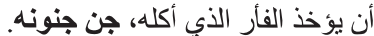

$$
\begin{aligned}
& \text { (Bad.: 65) }
\end{aligned}
$$

(Ğab. y Mas.: 47)

«Irritarse con enfado grande y casi desesperación» según el Diccionario de lengua castellana de la Real Academia Española (I732), o «irritarse o encolerizarse», según el Diccionario fraseológico documentado del español actual (DFDEA) de Manuel Seco (2004), es el sentido de la locución española, que no difiere tanto del sentido que da el Diccionario de expresiones fraseológicas en árabe moderno ${ }^{6}$ (DEFAM) de Fayed Kamel

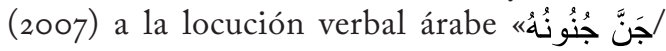
ğanna ğunūnubu», que es «excitarse, montar en cólera». La traducción literal de la locución árabe empleada por Badawī, y consecuentemente por Ğabrūnī y Masārī, es «volverse loco

\footnotetext{
6 Es nuestra traducción del título árabe / دعجم التعابير الاصطلاحية في العربية المعاصرة al-ta'àbìr al-iștilāhhìyya fì al-'arabiyya al-mu àșira.
}

o sufrir un ataque de locura». La locución árabe, aunque no pertenece al mismo campo léxico de la UFO, sí comparte con ella el mismo concepto y la misma expresividad. Se trata aquí de la llamada «equivalencia parcial» que se produce, en términos de Corpas Pastor (2003: 227), «cuando una UF y su equivalente presentan diferencias de significado - denotativo o connotativo-; distintas restricciones en los niveles diatópico, diafásico y diastrático; o bien diferencias formales o estructurales».

En la traducción de la UF española, Badawī recurre a la sustitución, técnica que Corpas Pastor (2003: 218) recomienda que se siga en los casos de equivalencias que sufren divergencias «en cuanto al contenido semántico o las restricciones diasistemáticas de las UFS implicadas».

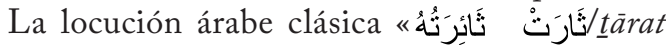
$\underline{t} \bar{a}^{\prime}$ iratubu [excitarse]», que el DEFAM con-

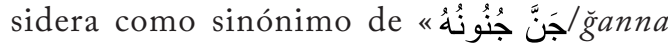
ğunūnuhu», pudiera ser también otro posible equivalente fraseológico. Del mismo modo, con el actante principal de la locución española, esto es el diablo, los diccionarios fraseológicos árabes

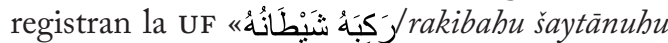
[le montó el diablo]»(DCEF y DEFAM), que ofrecemos también como otro equivalente fraseológico.

La sustitución es de nuevo la técnica empleada en el caso siguiente:

Parescióme que en aquel instante desperté de la simpleza en que, como niño, dormido estaba. Dije entre mí: «Verdad dice éste, que me cumple avivar el ojo y avisar, pues solo soy, y pensar cómo me sepa valer». (Rico: 23)

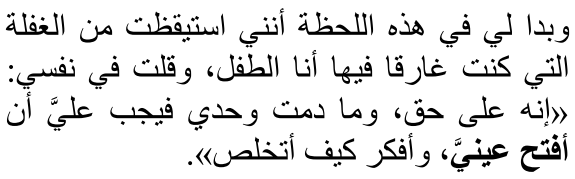

(Bad.: 42) 


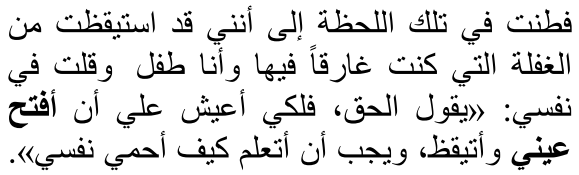

(Sa'd.: I9)

وبدا لي في هذه اللحظة أنني استيقظت من الغفلة

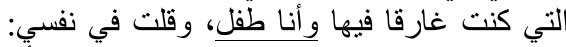

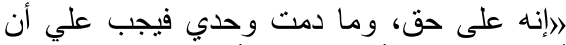

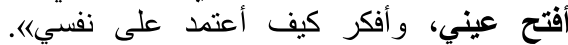

(Ğab. y Mas.: 26)

El sentido de la locución verbal avivar el ojo, que es «andar con cuidado y diligencia para no dejarse engañar ni sorprender» (DRAE), es el mismo que ofrecen el DEFAM y el DCEF para

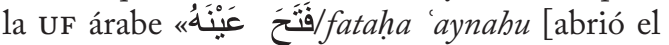
ojo]». La UFo denota una acción conceptualizada y lexicalizada en la LM. La expresión idiomática ofrecida en las tres traducciones árabes es un equivalente parcial que ha sido elegido pasando por las técnicas actancial y temática. El concepto de precaución está expresado en las dos locuciones, la española y la árabe, aunque con verbos diferentes: «avivar» en el TO

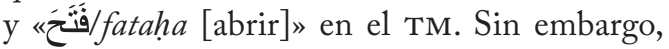
dicha leve diferencia no afecta tanto en el sentido, sobre todo que las dos UFs tienen el mismo nivel de uso y el mismo grado de circulación.

\subsubsection{Traducción mediante un lexema}

Sustentando la opinión de Roda Roberts (1998: 75-76), Corpas Pastor (2003: 284) ofrece tres soluciones para la traducción de una UF: mediante otra UF equivalente en la LM; mediante una paráfrasis de su contenido semántico; o mediante una sola palabra. Esta última técnica, aunque es menos recomendada en el ámbito de la traducción fraseológica (Pedersen, I997: ro9; ápud Corpas Pastor, 2003: 309), se emplea con frecuencia en los textos árabes comentados, como revelan los dos ejemplos siguientes:

Algunos hombres honrados que allí estaban se quisieron levantar y echar al alguacil fuera de la iglesia, por evitar escándalo. Mas mi amo les fue a la mano y mandó a todos que, so pena de excomunión, no le estorbasen,

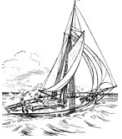

127 mas que le dejasen decir todo lo que quisiese. (Rico: II8)

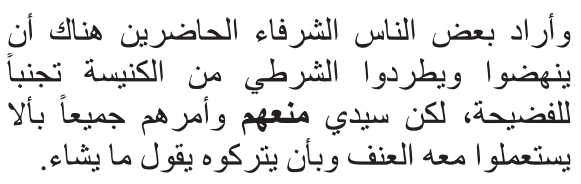

(Bad.: 98)

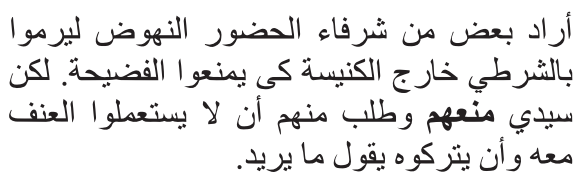

(Sa'd.: 7I)

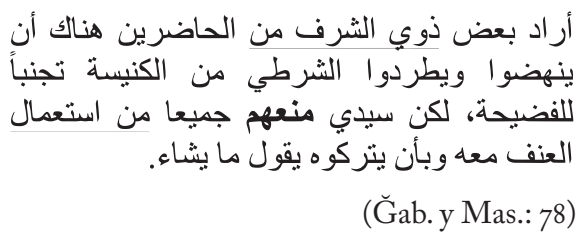

La locución verbal Ir a la mano a alguien, que significa «contener [le] o moderar [1e]» (DFDEA), ha sido traducida en las tres versiones mediante el verbo "مَنَعَ/mana'a [prohibió o impidió]». Para dicha UFo hemos encontrado una posible correspondencia fraseológica en la LM. La locución verbal árabe clásica

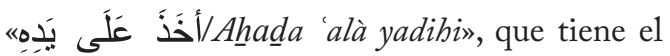
sentido de contener a alguien y prohibirle de hacer algo (DCEF y DEFAM), mantiene muchas coincidencias con la UFO. Junto con el concepto, el valor semántico, el sentido connotativo y la base figurativa, ambos fraseologismos tienen el mismo actante, que es, en este caso, la mano. No obstante, no podemos hablar de una 
equivalencia plena, sino parcial, porque las dos UFS no coinciden totalmente en cuanto a los componentes léxicos, ya que, mientras el verbo núcleo de la locución española es «ir», el de su equivalente árabe es «أخَذَّitomar]». Además, al contrario de la locución verbal española caracterizada por su uso raro (DFDEA), la UF árabe es más frecuentemente usada.

Otra locución verbal que ha sido traducida por una sola palabra aparece en el tratado $\mathrm{V}$, en el episodio que cuenta la pelea del buldero (amo de Lázaro) con el alguacil:

[...] viendo que no podían afrentarse con las armas, decíanse palabras injuriosas. Entre las cuales el alguacil dijo a mi amo que era falsario y las bulas que predicaba que eran falsas. Finalmente, que los del pueblo, viendo que no bastaban a ponellos en paz, acordaron de llevar al alguacil de la posada a otra parte. (Rico: Ir6)

الأ...] ولما شاهد كلاهما أنه لا يسنطيع أن يهاجم

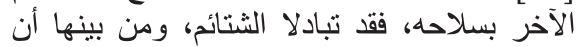

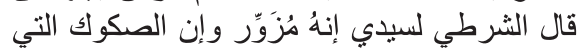

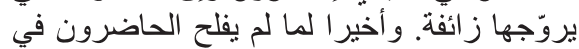

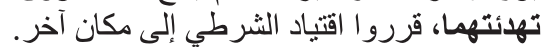

(Bad.: 97)

[... [لما شاهدا نفسيهما بلا حول، عادا لتبادل الشتائم وكان أن عاد الشرطي ليقول لسيدي بأنه

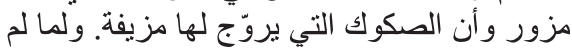

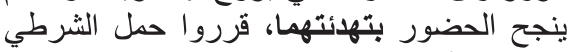
إلى مكان آخر .

(Sa'd.: 7o)

الاخر ب...] ولما شاهد كلاهما أنه لا يستطيع أن بهاجم

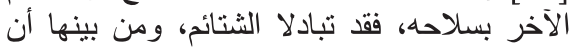

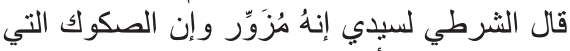

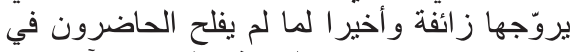

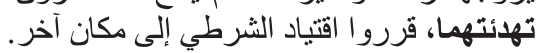

(Ğab. y Mas.: 77)
E1 buldero y el alguacil se luchan y se acusan mutuamente, y la gente, testigo de la riña, fracasan en "hacer que cese [1a] pelea» (DFDEA) y en «interponerse entre quienes riñen» (DRAE) para reconciliar y restablecer la paz entre ambos. La locución verbal «poner en paz [a dos o más personas]» (DRAE) refleja el sentido escrito en cursiva en la oración anterior. En las tres traducciones al árabe no sólo se opta por transmitir el significado fraseológico mediante una sola palabra, sino también se emplea un vocablo erróneo cuyo sentido queda muy lejos del de la UFO. Así, al lector del To se presenta una escena en la que la gente media y se interpone para hacer las paces entre el buldero y el alguacil, mientras que el lector del TM entiende que el público testigo de la riña intenta «calmar» a los peleados sin que ello implique necesariamente ponerlos en paz. A diferencia de la locución poner en paz que exige que su acusativo sea «dos o más personas» (DRAE), la acción del

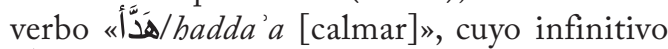

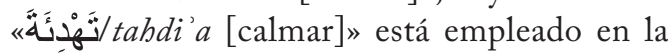
traducción, puede pasar indistintamente a una o a varias personas.

Esta pérdida de una parte del sentido habría sido evitada si los traductores hubieran recurrido a la locución verbal clásica /أصنلَحَ ذَاتَ الْبَيْن așlaḥa dēt al-bayni» que significa acabar con la riña y reconciliar entre los peleados (DEFAM). Recomendamos el uso de esta UF árabe porque mantiene una equivalencia, aunque parcial, con su correspondiente española, ya que ambas reflejan el mismo concepto, poseen el mismo significado connotativo y se emplean con frecuencia en los mismos contextos en las dos culturas.

\subsubsection{Reducción al sentido}

En las versiones árabes del Lazarillo abundan los casos en que se reduce al sentido de la 
locución original, técnica que más esperábamos encontrar porque no es una tarea fácil encontrar equivalentes fraseológicos, plenos o parciales, entre dos lenguas tan diferentes como son la española y la árabe. A modo de ilustración, citamos los siguientes ejemplos:

- Lázaro, esta agua es muy porfiada, y cuanto la noche más cierra, más recia. Acojámonos a la posada con tiempo». (Rico: 44)

$$
\begin{aligned}
& \text { ״اي لثرو، هذا الماء مستمر، وكلما دخل الليل ازداد }
\end{aligned}
$$

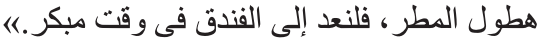

(Bad.: 53)

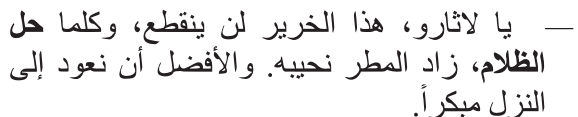

(Sa'd.: 29)

_ - ـ يا لاثرو، هذا المطر عنيد، وكلما دخل الليل ازداد هطو لا فلنعد إلى الفندق باكر ا.

(Ğab. y Mas.: 36)

Como es bien sabido, la mayor parte de ideas, fenómenos y experiencias son universales, pero lo que se cambia es la forma de expresarlos en una y otra lengua. Así, como se puede notar en el ejemplo, con la locución verbal metafórica cerrar la noche se refiere al tiempo cuando se pasa «del crepúsculo vespertino a la falta total de la luz del día» (DRAE). El mismo fenómeno natural se expresa en árabe, entre otras formas, mediante la locución clásica figurativa

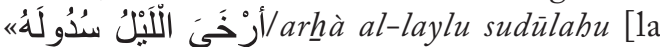
noche dejó caer sus velos]» (DCEF) que proponemos como equivalente parcial.

En las tres versiones árabes del Lazarillo se reduce al sentido de esta UFO, técnica que es menos recomendada porque, según Newmark (1995: 155), «los componentes semánticos no sólo se perderán o añadirán, sino que el impacto emotivo o pragmático quedará mermado o desaparecerá». Esta pérdida pragmática y estilística se muestra obviamente en la traducción de la

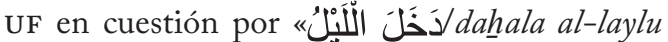
[la noche entró]», en la primera y tercera ver-

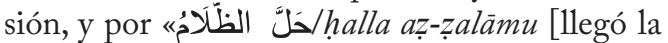
oscuridad]», en la segunda.

Otra pérdida del valor figurativo y estilístico de una expresión idiomática conlleva la transferencia al árabe de la locución adverbial en buen romance mediante la reducción al sentido, en la primera y tercera traducción, y mediante la paráfrasis, en la segunda:

$Y$ es que tengo cargo de pregonar los vinos que en esta ciudad se venden, y en almonedas, y cosas perdidas, acompañar los que padecen persecuciones por justicia y declarar a voces sus delictos: pregonero, hablando en buen romance. (Rico: 129)

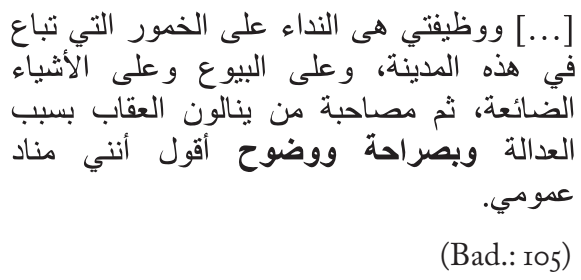

[...] و عملي كمُناد على الخمور التي تباع في هذه

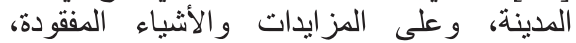
وكذلك مر افقة من يعاقب باسم العدالة والتصريح

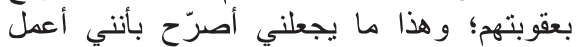

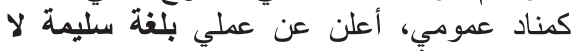
تشوبها شائبة. (Sa d.: 79-80)

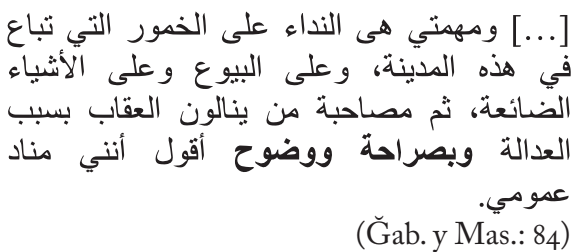

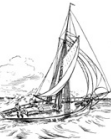

129 
La combinación fraseológica en buen romance no existe en árabe porque el vocablo «romance» se aplica a las lenguas derivadas del latín, por esta razón dicha locución adverbial no tiene equivalencia plena, pero sí puede ser sustituida por más de una locución árabe del mismo sentido fraseológico, aunque de componentes léxicos distintos. El sentido de hablar «claramente y de modo que todos lo entiendan» (DRAE), que dicha locución refleja con un cierto grado de opacidad, se reproduce en la primera y tercera

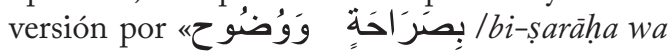
wudūh [franca y claramente]», y en la segunda

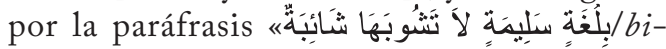
luga salìma lā tašübu-bā ša ${ }^{\prime} i b a$ [con una lengua correcta y sin tacha]».

Los diccionarios árabes ofrecen unidades lingüísticas estables que presentan el mismo sentido de hablar con claridad, como, por ejem-

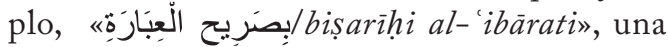
locución adverbial cuya traducción literal es «con la claridad de la frase». Según el DEFAM, esta UF significa «con claridad, sin ambigüedad ni ambages».

\subsubsection{Traducción literal}

En no pocas ocasiones se da el caso en que los traductores no se dan cuenta de los indicios de idiomaticidad que llevan algunos fraseologismos cuya lectura literal no tiene sentido en su contexto. La reproducción literal de cualquiera de estas UFS carece de sentido y complica el entendimiento del lector del TM. Como ejemplo, citamos los dos casos siguientes:

Cuando el pobreto iba a beber, no hallaba nada, espantábase, maldecíase, daba al diablo el jarro y el vino, no sabiendo que podía ser. (Rico: 32 )

وكان ينده، ويلعن، ويرمي الشيطان بالكوز والنبيذ

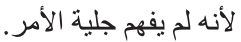

(Bad.: 46)

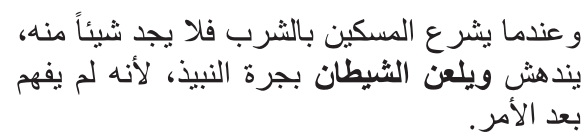

(Sa'd.: 22)

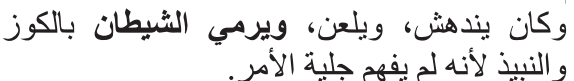

(Ğab. y Mas.: 29)

- Toma, Lázaro, que Dios ya va abriendo su mano. Ve a la plaza, y merca pan y vino y carne: ¡quebremos el ojo al diablo! (Rico: 95)

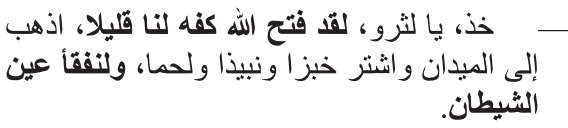

(Bad.: 84)

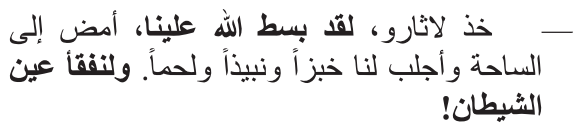

(Sa d.: 58-59)

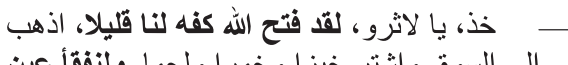

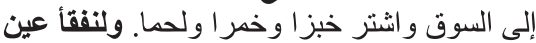

الشيطان.

(Ğab. y Mas.: 66)

En el primer caso tenemos la locución verbal española dar al diablo, cuyo sentido establecido a partir de la combinación de los significados de sus elementos componentes no es entendible ni aceptable lógicamente. Reconociendo el carácter idiomático de dicha unidad, el diccionario académico indica que se emplea para «manifestar desprecio o indignación hacia [alguien o algo]» (DRAE).

La traducción palabra por palabra propuesta en la primera y tercera versión carece totalmente de sentido para el lector árabe. Si bien es cierto que en los diccionarios fraseológicos árabes consultados no hemos encontrado equivalente 
total o parcial de esta unidad, sí se podría haber reproducido el sentido de la locución mediante

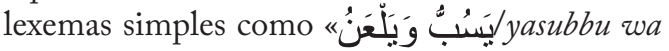
yal'anu [insulta y maldice]».

En el segundo ejemplo los traductores tampoco reconocen la locución verbal española quebrar [alguien] el ojo al diablo, y ofrecen en sus respectivas versiones una traducción palabra por palabra que reproduce la lectura literal de la UFO. Mientras el fraseologismo del To significa «hacer lo mejor, más justo y razonable» (DRAE), su reproducción literal en las traducciones árabes significa «arrancar un ojo al diablo», lo que no tiene sentido, extranjeriza al TM y hace visible al traductor.

El mismo ejemplo contiene la locución verbal abrir la mano que significa «dar con liberalidad» (DRAE). La oración en que está insertada la locución corrió en la boca del pobre clérigo cuando ganó dinero y sintió que Dios le había dado con liberalidad. La traducción literal empleada en la versión de Badawī, y por consecuencia en la de Ğabrūnī y Masārī, no tiene sentido alguno, ya que, para un lector árabe la imagen que lleva la UF resulta extraña.

En cambio, el equivalente que ofrece Sa dūn, 《بَنَ'basața Allābu 'alaynā», que quiere decir que Dios le dio con generosidad y largueza al clérigo, aunque no está registrado en los diccionarios fraseológicos consultados, sí transmite el sentido y despierta en el lector árabe las mismas reflexiones provocadas en el lector del To. Un factor que quizá contribuye a que el lector del TM capture el sentido connotativo de esta frase es su raíz coránica en el versículo

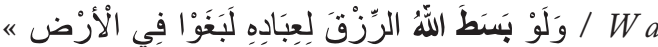
law basața Allāhu ar-rizka li- 'ibādibi la-baḡaw $f i-l$-ardi $[\mathrm{Si}$ Dios dispensara el sustento a sus siervos con largueza, se insolentarían en la tierra $\left.^{7}\right]$ ». El mismo sentido lo tiene la UF árabe

7 Sūra 42 «الشورى/Ǎšš̄ra [La Consulta], versículo 27.

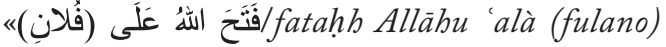
[Dios le abrió a fulano]» (DCEF y DEFAM), que también posee una raíz coránica al ser citada con la misma connotación semántica

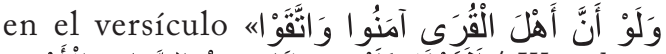

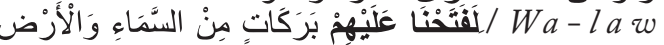
anna abla-l-kurà àmanù wa-t-takaw la-fatahnnà 'alaybim barakātin min-as-samā'i wa-l-ardi $[\mathrm{Si}$ los habitantes de las ciudades hubieran creído y temido a Dios, habríamos derramado sobre ellos bendiciones del cielo y de la tierra ${ }^{8}$ ]».

\subsubsection{Falsos amigos}

Este fenómeno lingüístico de «equivalencia aparente» tiene lugar «en aquellas unidades de la LO y la LM que presentan similitud formal con respecto a sus elementos constitutivos, pero diferencia semántica» (Corpas Pastor, 2003: 208-209). El siguiente caso es un ejemplo de la modificación de significado producida por los llamados «falsos amigos»:

-Marido y señor mío: ‘adónde os me llevan? ¡A la casa triste y desdichada, a la casa lóbrega y obscura, a la casa donde nunca comen ni beben!

Yo, que aquello oí, juntóseme el cielo con la tierra, y dije:

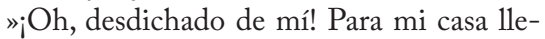
van este muerto». (Rico: 96)

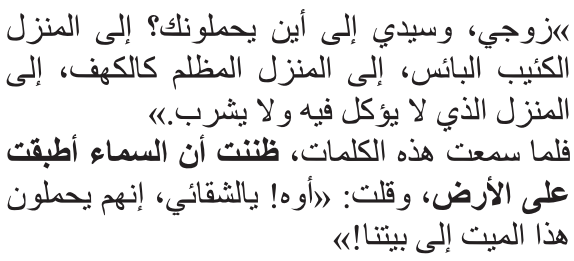

(Bad.: 85)

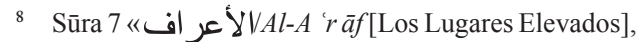
versículo 96. La traducción de los dos versículos coránicos es de Julio Cortés (2005). 


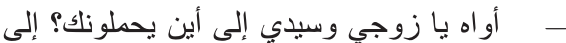

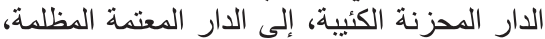

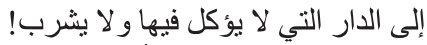

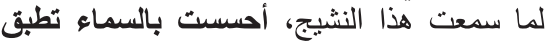

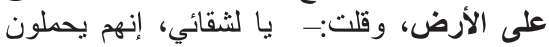

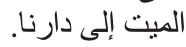

(Sa'd.: 59)

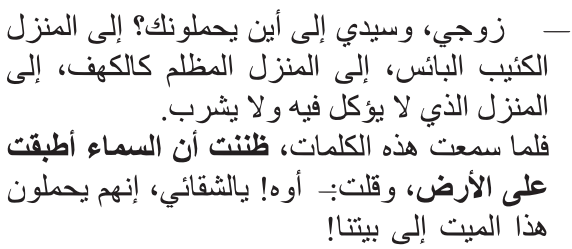

(Ğab. y Mas., 2007: 66-67)

Para un mejor entendimiento de este ejemplo, que contiene una anécdota, es importante contextualizarlo primero. En este tratado, Lázaro cuenta su vida con el pobre escudero en una casa donde no hay nada para comer, y que, en palabras del amo, es lóbrega, triste, oscura y trae mala suerte. Un día, en su camino al mercado para comprar pan y vino, Lázaro ve a la gente llevando a un muerto, cuya mujer va llorando y gritando a voces que lo llevan a la casa triste y desdichada, lóbrega y oscura donde no se come ni se bebe, refiriéndose al cementerio. Lázaro, al escuchar esto, se le cae el mundo encima porque piensa que lo llevan a la casa de su $\mathrm{amo}^{9}$.

Para expresar su temor, confusión e inseguridad tras haberse visto «impensadamente en un trance grave» (DRAE), Lázaro emplea la locución verbal juntársele [a alguien] el cielo con la tierra. La UF árabe presentada en las tres ver-

9 Esta anécdota es idéntica al cuentecillo árabe al que hemos aludido en el apartado 2 . siones, cuya traducción literal es «aun cuando el cielo tape la tierra», tiene un sentido totalmente diferente indicando «la imposibilidad de que algo suceda» (DEFAM e Ibn Manzūr, 6307II=I999, VIII: I20). A primera vista, las dos UFS resultan aparentemente equivalentes por tener los mismos componentes léxicos; no obstante, cada una tiene un sentido diferente y se emplea en contextos totalmente distintos.

El estado del asustado e intranquilo por haberse encontrado en una situación crítica lo expresa el refrán árabe clásico ه / L a a yăgidu fì as-samā' $i$ maș 'adan wa là fì al-arḍi mak'adan [no encuentra escalera al cielo ni asiento en el suelo]». Se refiere a la persona a quien el miedo se le intensifica, y la confusión y la perplejidad le dominan tanto que no encuentra adónde refugiarse (Sịnī, I992). Esta paremia árabe propuesta cubre los aspectos tanto pragmáticos como funcionales de la UFO, aunque ambas unidades lingüísticas difieren en cuanto a los otros aspectos léxico-semánticos y sintácticos.

\subsubsection{Equivalencia nula}

Los vacíos referenciales entre una y otra lengua, derivados en muchos casos de la existencia de UFs con cierto componente cultural, dan lugar a una falta de equivalentes fraseológicos:

Se trata de UFS de la LO que denotan realidades y situaciones no conceptualizadas, y, por tanto, no lexicalizadas, en la LM. [...]. Por lo general, estamos ante unidades que reflejan un aspecto idiosincrásico de la cultura de la comunidad de origen. (Corpas Pastor, 2003: 217)

Un ejemplo ilustrativo de la falta de correspondencias fraseológicas es el siguiente:

$\mathrm{Y}$ venimos a este camino por los mejores 
lugares. Donde hallaba buena acogida y ganancia, deteníamonos. Donde no, a tercero día hacíamos Sant Juan. (Rico: 35 )

وجئنا إلى هذا الطريق عابرين بخير القرى.

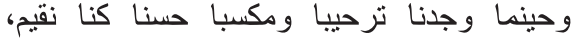
وحينما لم نجد شيئا، كنا نرحل في اليوم الثالثا.

(Bad.: 48)

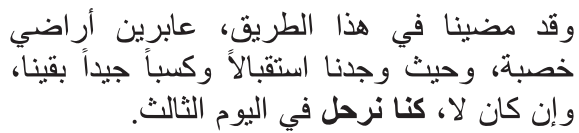

(Sa'd.: 24)

وجئنا إلى هذا الطريق عابرين بخير القرى وحينما لم نجد شيئا، كنا نرحل في اليوم الثالث.

(Ğab.y Mas.: 3I)

La definición que el diccionario académico da a la locución verbal hacer [los mozos asalariados] San Juan es «despedirse antes de cumplir el tiempo de su ajuste» (DRAE). Un estudio minucioso del fondo histórico-cultural de dicha UF revela que ésta se remonta a una costumbre muy antigua relacionada con el día de San Juan, cuando se solía «mudarse de una casa a otra, [...] despedirse los mozos y dejar el amo o despedirse de él» (Correas, r627=ı906: 194).

Lázaro, cuando dice que él y su amo ciego hacían San Juan al no encontrar ganancia en las ciudades a que viajaban, significa que se despedían y abandonaban el lugar en busca de otro mejor, tal como solían hacer los mozos en el día de San Juan. Para el lector del to no es difícil interpretar esta locución ni entender su sentido; en cambio, para un lector árabe, perteneciente a una cultura diferente, le resulta imposible descifrar esta unidad lingüística y capturar su significado sin la ayuda del traductor. En este caso, los traductores del Lazarillo, dándose cuenta de que la traducción literal de esta UF no tiene sentido, optan por una traducción mediante un verbo que represente el acto de partir o marcharse. En las tres versiones, la UFO se traduce por el verbo "كُنَّا نَرْخل kunnā narhal [partíamos], y se añaden en las traducciones de Badawī y Sa 'dūn una nota final, en el primer caso, y otra a pie de página, en el segundo, que aluden a la raíz cultural que tiene la UF en cuestión.

Otro ejemplo de la carencia de equivalencia es el siguiente:

Y, por evitar prolijidad, desta manera estuvimos ocho o diez días, yéndose el pecador en la mañana con aquel contento y paso contado a papar aire por las calles, teniendo en el pobre Lázaro una cabeza de lobo. (Rico: 9I)

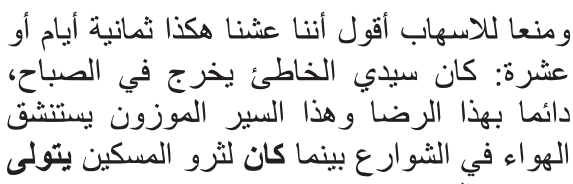

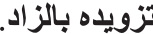

(Bad.: 82)

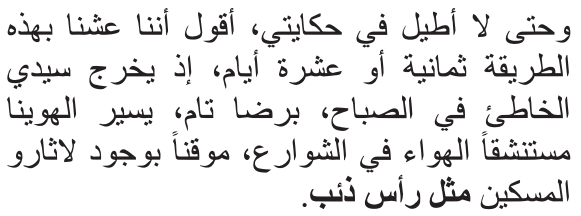

(Sa 'd.: 57)

وحتى لا أسهب في الكلام أقول أننا عشنا هكذا

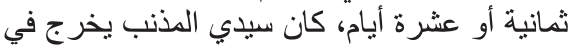

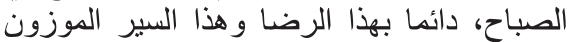

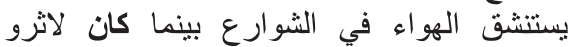
المسكين يتولى إطعامه.

(Ğab. y Mas.: 63)

Lázaro vive miserablemente con el escudero arruinado cuya apariencia engañaba e indicaba que tenía poder y posesiones. Con este amo Lázaro pasaba más hambre, lo que le obligó a salir a la calle pidiendo a la gente comida que bastara a ambos, y así, en vez de que el amo ali-

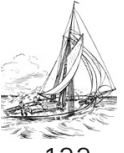

133 
mentara al mozo, tal como esperaba Lázaro, fue éste quien asumía la responsabilidad de nutrir a su amo, el cual pasaba su día paseando. Esta paradoja le recordó a Lázaro de la tradición antigua de los hombres que mataban a lobos $y$, para aprovecharse de la ocasión en beneficio propio, andaban enseñando a la gente la cabeza del lobo muerto pidiéndole dinero por haberle liberado de esta fiera. De esta manera, la cabeza del lobo se convirtió en el medio a través del cual se alimentaba el astuto cazador.

Sa dūn recurre a la traducción literal e inserta una nota a pie de página que explica el sentido de la unidad lingüística. Esta extranjerización, aunque preserva el sabor de la LO, ofrece una traducción carente de sentido para el lector árabe, haciéndole sentir que está ante una obra de segunda mano.

Ante la ausencia de equivalentes fraseológicos en la LM, Corpas Pastor (2003: 217-218) sugiere que el traductor trabaje «a partir de una paráfrasis de la carga semántica, pragmática y discursiva de la UF en el TO, valorando las posibilidades que le ofrecen los distintos procedimientos (oblicuos y directos) de traducción». Y esto es lo que Badawī (I979) y Gabrūnī y Masārī (2007) han hecho en sus respectivas versiones, aunque, en este caso, con expresiones no idénticas, reduciendo la UFO a su sentido:

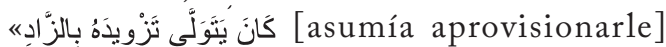

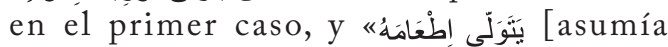
alimentarle] en el segundo.

Un caso interesante que merece la pena mencionar es el de la UF oler el poste:

Aun apenas lo había acabado de decir, cuando se abalanza el pobre ciego como cabrón y de toda su fuerza arremete, tomando un paso atrás de la corrida para hacer mayor salto, y da con la cabeza en el poste, que sonó tan recio como si diera con una gran calabaza, y cayó luego para atrás medio muerto y hendida la cabeza

- ¿Cómo, y olistes la longaniza y no el poste? ¡Olé, olé! —le dije yo. (Rico: 45 )

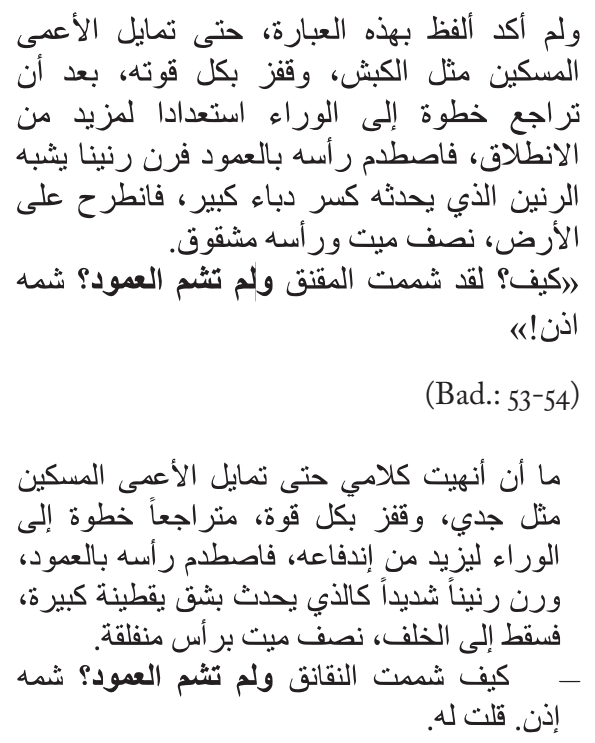

(Sa'd.: 30)

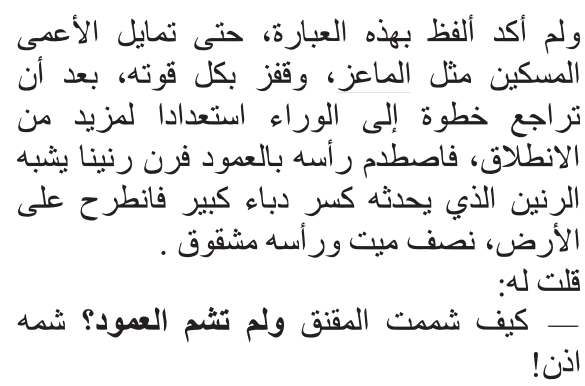

(Ğab. y Mas.: 37)

En esta parte de la obra Lázaro y su amo ciego andaban en un estrecho paso inundado por la lluvia. El ciego pidió a Lázaro que le ayudara al cruzar el riacho detrás del cual había un poste de piedra. Lázaro puso a su amo enfrente 
del poste y le dijo que saltara, y éste, confiando en su mozo, saltó y topó con las narices y la cara en el poste tal que quedó inconsciente en el acto. Lázaro rió y le dijo su famosa frase: «¿Cómo, y olistes la longaniza y no el poste?». Antes de esta situación, el ciego había metido su nariz en la boca de Lázaro para averiguar si éste había comido longaniza o no, y al asegurarse de que sí la había comido, lo castigó. $\mathrm{El}$ accidente del poste constituye la venganza de Lázaro, lo que se manifiesta en su célebre pregunta irónica que significa «¿cómo oliste la longaniza en mi boca y no pudiste oler el poste para evitar chocar con él?».

Lo que nos interesa más en este caso es el origen de la unidad lingüística oler el poste, que Cabrera y Ayegui (I837: 490), Sbarbi (I891, II: 263) y Correas (1627=1906: 154 ) aseguran que es el cuento mismo de Lázaro y su amo.

En las tres traducciones la UFO ha sido tra-

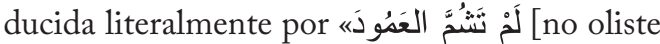
el poste]». Es una de los muy raros casos en que nos resulta justificada la literalidad de traducción, por una parte porque antes de que el autor anónimo de la obra pusiera en boca de Lázaro la frase en cuestión, ésta no había sido considerada como unidad fraseológica. Es decir, el significado intencionado del autor fue el literal, o sea, la suma de los significados de los dos elementos lingüísticos componentes de la expresión sin ningún grado de idiomaticidad fraseológica. Más tarde, como ocurre con las UFs basadas en referencias culturales o históricas, esta frase se convirtió en una unidad fraseológica con un alto grado de idiomaticidad para referirse a «la falta de sagacidad de alguna persona que, dejándose llevar fácilmente de su credulidad, no ha podido prever los inconvenientes a fin de evitarlos» (Sbarbi, I89I, II: 263). Por otra parte, para el lector árabe, la descodificación de esta unidad no presenta problema alguno, pues las circunstancias del cuento del poste, precedido por la situación de la longaniza, revelan la previa intención de venganza que tenía Lázaro hacia su amo, lo que facilita el entendimiento del sentido de dicha frase.

\section{CONCLUSIONES}

En este artículo nos hemos sustentado principalmente en el planteamiento de Newmark (1995) y Corpas Pastor (I996 y 2003) que sugieren que, ante la dificultad que supone la traducción fraseológica, no faltan las posibles estrategias de traducción que reproduzcan, en la medida de lo posible, las mismas cargas semánticas, pragmáticas y discursivas de las uFs. Del mismo modo, nos hemos apoyado en las técnicas esbozadas por Julia y Manuel Sevi1la Muñoz (2000, 2004a, 2004b, 2005a, 2005b y 2005c) para la traducción de paremias. A lo largo del estudio hemos examinado las estrategias de traducción fraseológica empleadas en las tres versiones árabes del Lazarillo, proponiendo, en muchos casos, posibles equivalentes fraseológicos y paremiológicos localizados de acuerdo con las técnicas traductológicas presentadas por los autores que acabamos de mencionar.

En cuanto al análisis de la traducción de las locuciones, aun cuando hay casos de traducción inacertada, e incluso errónea en algunas ocasiones, los traductores han conseguido encontrar soluciones para unas situaciones problemáticas empleando algunas de las técnicas recomendadas para la traducción fraseológica. Las estrategias de transferencia de locuciones del Lazarillo han variado desde la sustitución, en casos de equivalencias fraseológicas totales y parciales, hasta la traducción literal, la reducción al sentido, la paráfrasis y la traducción mediante lexemas simples. No obstante, se puede concluir que los traductores tienden generalmente a la

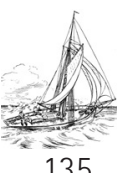

135 
literalidad y a la transferencia del sentido de la mayoría de las locuciones del To, aunque algunas de ellas tienen equivalentes árabes con los mismos valores connotativos y expresivos.

En cuanto a la transferencia de paremias, la literalidad ha sido el único procedimiento empleado en las tres traducciones, incluso en los casos en que se trata de refranes que tienen equivalentes paremiológicos totales o parciales.

El estudio de casos revela que el reducido número de expresiones idiomáticas insertadas en las traducciones del Lazarillo, obra famosa por su abundancia de paremias y fraseologismos, no puede considerarse como intencionado, sino que puede ser debido a la incapacidad de los traductores de reconocer las UFS del TO o de encontrar equivalentes para las UFs interpretadas. Sin embargo, la merma de algunos detalles connotativos y expresivos, así como la pérdida de las cargas pragmáticas, semánticas y discursivas, causadas por la traducción de fraseologismos por elementos lingüísticos no fraseológicos, han sido compensadas en parte insertando en el texto árabe unidades fraseológicas no presentes en el TO.

El análisis de casos y la búsqueda de correspondencias fraseológicas y paremiológicas que hemos llevado a cabo han mostrado, como era de esperar, que los dos sistemas fraseológicos, el español y el árabe, no son tan lejanos, sino que muestran algunos rasgos en común y presentan varios grados de equivalencia entre sus respectivas UFS. Así, en el plano conceptual, no resulta imposible hallar analogías entre las dos lenguas; no obstante, a nivel léxico y textual, las posibilidades de encontrar correspondencias se reducen notablemente.

RECIBIDO EN MAYO DE 2012 ACEPTADO EN SEPTIEMBRE DE 2012 VERSIÓN FINAL DE SEPTIEMBRE DE 2OI3

\section{BIBLIOGRAFÍA}

\section{Fuentes primarias}

Badawī, A. (trad.) (I979). Hayāt Latariyyū di Turmis [La vida de Lazarillo de Tormes]. Madrid: Instituto Hispano-Árabe de Cultura.

Ğabrūnī, I. al- y Masārī, M. al- (trads.) (2007). Latariyyū di Turmis [Lazarillo de Tormes]. Tánger: Ediciones Litograf.

Rico, F. (ed.) (1554=2000). Lazarillo de Tormes. Madrid: Cátedra.

Sa 'dūn, A. (trad.) (20or). Latariyyū di Turmis. Maqamāt Latarū [Lazarillo de Tormes: Las maqamas de Lázaro]. Amman / Madrid: Azmina li-1-Našr wa-1-Tawzī' / Dār Alwāḥ.

\section{Fuentes secundarias}

Ayala, F. (I965). «Fuente árabe de un cuento popular en el "Lazarillo"". Boletín de la Real Academia Española XLV, I76, pp. 493-496.

- (1971). El Lazarillo: nuevo examen de algunos aspectos. Madrid: Taurus.

Baker, M. (1992). In Other Words: A Coursebook on Translation. London: Routledge.

Bakrī, Abū 'Ubaid al-. (1971). Faṣl al-makāl fĩ saarh kitāb al-amtāl [La última palabra en la explicación del libro de refranes]. Iḥsān 'Abbās (ed.). Beirut: $\mathrm{Mu}$ 'asasat ar-Risāla.

Bezos, J. (2005). Tex y tipografía. <http://www.textipografia.com/archive/TransArabe.pdf> [Consulta: 5 mayo 2011$]$.

Cabrera, R. y Ayegui, J. P. (1837). Diccionario de etimologias de la lengua castellana [en línea]. Madrid: Imprenta de Don Marcelino Calero <http://archive.org/stream/diccionariodeetoocabrgoog\#page/ no/mode/2up> [Consulta: 2 abril 2OI2].

Casares, J. (1950=1992). Introducción a la lexicografia moderna, Madrid: SCIS, 1992.

Corpas Pastor, G. (1996). Manual de fraseología española. Madrid: Gredos.

- (2003). Diez años de investigación en fraseología: Análisis sintáctico-semánticos, contrastivos y traductológicos. Frankfurt am Main/Madrid: Vervuert/ Iberoamericana.

Correas, G. (1627=1906). Vocabulario de refranes y frases proverbiales y otras fórmulas comunes de la lengua castellana en que van todos los impresos antes y otra 
gran copia [en línea]. Madrid: Establecimiento Tipográfico de Jaime Ratés <http://www.archive. org/stream/vocabularioderefoocorruoft\#page/n3/ mode/2up> [Consulta: II enero 20I2].

Cortés, J. (trad.) (2005). El Sagrado Corán [en línea]. San Salvador: Centro Cultural Islámico Fātimah Az-Zahrā' <http://www.islamelsalvador.com/ sagradocoran/elsagradocoran.pdf> [Consulta: 3 abril 20I2].

De la Granja, F. (197I). « Nuevas notas a un episodio del "Lazarillo de Tormes" [en línea]. Al-Andalus 36 (I), pp. 223-236.

Del Monte, A. (1971). Itinerario de la novela picaresca española. Barcelona: Lumen.

Fayed Kamel, W. (2007). Mu' ‘̆am al-ta'ābir al-iștilāhinyya fì al- 'arabiyya al-mu'āṣira [Diccionario de expresiones fraseológicas en árabe moderno]. El Cairo: Abū al-Hawl [DEFAM].

Flavio Aviano, F. (1998). Fábulas [en línea]. Manuel Mañas Núñez (ed.). Madrid: Akal <http://historiantigua.cl/wp-content/ uploads/20II/o7/29858540-Aviano-Fabulas-Bilingue.pdf> [Consulta: I4 marzo 2012].

García Gómez, E. (1977). «Una prueba de que el refranero árabe fue incorporado en traducción al refranero español». AI-Andalus 42 (2), pp. 375-39o.

Ibn Manẓūr, G. (630-7II=I999). Lisānu-l-'arab [Lengua de los árabes]. 'Abd al-Wahhāb, A.M. y Al- 'Ubaydī, M. Ș. (eds). Beirut: Dār Iḥyā’ al-Turāt al-'Arabī y Mu' assasat at-Tārīh al- 'arabī.

Maydānī, A. al-. (ı838-ı843=1955). Mağma' al-amțāl [Compendio de refranes]. Muḥammad Muhȳīd-dīn 'Abd al-Hamīd (ed.). El Cairo: Mața'at al-Sunna al-Muhammadiyya.

Newmark, P. (I995). Manual de traducción. Virgilio Moya (trad.). Madrid: Cátedra.

Outmānī, I. al-. (2007). «Picaresca» [en línea]. Espéculo. Revista de estudios literarios 35 <http://www. ucm.es/info/especulo/numero35/picaresc.html> [Consulta: I7 diciembre 20II].

Penadés Martínez, I. (I999). La enseñanza de las unidades fraseológicas. Madrid: Arco Libros.

Real Academia Española (I732). Diccionario de lengua castellana, en que se explica el verdadero sentido de las voces, su naturaleza y calidad, con las phrases o modos de hablar, los proverbios o refranes, $y$ otras cosas convenientes al uso de la lengua [en línea]. III <http://books.google.com.eg/books?id=frxKAAA AcAAJ\&pg=PA2I\&dq=darse + al + diablo\&hl=en\& ss $=$ X\&ei $=$ w HuaT62 Kc8eZ8gOor4mcDw\&ved $=$ oCGoQ6AEwCQ\#v=onepage\&q\&f=false > [Consulta: 3 enero 20I2].

Real Academia Española (200I). Diccionario de la lengua española [DRAE]. 〈http://buscon.rae.es> [Consulta: I8 enero 20I2].

Ruiz Gurillo, L. (1998). La fraseología del español coloquial. Barcelona: Ariel.

Sbarbi, J. M. (1891). Monografía sobre los refranes, adagios y proverbios castellanos, y las obras o fragmentos que expresamente tratan de ellos en nuestra lengua [en línea]. Madrid: Imp. y Litografía de los Huérfanos <http://www.archive.org/ stream/monografiasobreloosbaruoft\#page/n7/ mode/2up> [Consulta: II enero 20I2].

Seco, M., Andrés, O. y Ramos, G. (2004). Diccionario fraseológico documentado del español actual: locuciones y modismos españoles. Madrid: Aguilar [DFDEA].

Sevilla Muñoz, J. (I997). "Fraseología y traducción» [en línea]. Revista Complutense de Estudios Franceses I2, pp. 43I-440 <http://revistas. ucm.es/index.php/THEL/article/view/THEL9797220497A/33885> [Consulta: 23 noviembre 2OII].

- (20II). «La técnica hiperonímica en la traducción de refranes y frases proverbiales» [en línea]. $E l$ trujamán. Io marzo $201 \mathrm{I}<\mathrm{http}: / /$ cvc.cervantes. es/trujaman/anteriores/marzo_II/IOO32OII.htm> [Consulta: 8 diciembre 20II].

Sevilla Muñoz, J. y Sevilla Muñoz, M. (200o). «Técnicas de la «traducción paremiológica» (francésespañol)». Proverbium I7, pp. 369-386.

- (2004a). «La técnica actancial en la traducción de refranes y frases proverbiales» [en línea]. El Trujamán. 8 noviembre 2004 <http://cvc.cervantes. es/trujaman/anteriores/noviembre_04/08II2004. htm> [Consulta: 7 mayo 2oII].

- $(2004 \mathrm{~b})$. «La técnica temática en la traducción de refranes y frases proverbiales» [en línea]. El Trujamán. 24 noviembre $2004<$ http://cvc.cervantes. es/trujaman/anteriores/noviembre_04/24III2004. htm> [Consulta: 7 mayo 2oII].

- (2005a). «La técnica sinonímica en la traducción de refranes y frases proverbiales» [en línea]. El Trujamán. 3 marzo 2005 <http://cvc.cervantes. es/trujaman/anteriores/marzo_05/03032005.ht> [Consulta: 7 mayo 20II].

- (2005b). «La traducción de paremias populares:

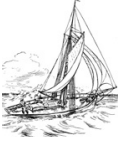

137 


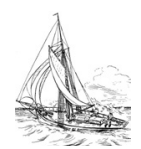

138 el refrán y la frase proverbial» [en línea]. El Trujamán. 2 septiembre $2005<$ http://cvc.cervantes. es/trujaman/anteriores/septiembre_05/02092005. htm> [Consulta: 7 mayo 2oIr].

- $(2005 \mathrm{c})$. «La aplicación de las técnicas de la «traducción paremiológica» a las paremias populares relativas al vocablo pez en español, inglés y francés» [en línea]. Revista de literaturas populares 5 (2), pp. 349-368 <http://www.rlp.culturaspopulares.org/textos/ıo/o8-Sevilla.pdf> [Consulta: 9 mayo 2OII].

Sevilla Muñoz, J. y Zurdo Ruiz-Ayúcar, M. (dirs.) (2009). Refranero multilingüe. Madrid: Centro Virtual Cervante <www.cvc.cervantes.es/lengua/ refranero $>$ [Consulta: 15 enero 20I2].
Ṣīnī, M. I, Abd al- 'Azīz, N. M. y Sulaimān, M. A. (I992). Mu'ğam al-amtāl al-'arabiyya [Diccionario de refranes árabes]. Beirut: Maktabat Lubnān.

—, Al-Tāhir Husayn, M. y Ad-Dawš, S. A. (I996). Al-mu' ğam al-siyāḳi li-l-ta 'bìrāt al-iṣtilāhhiyya [Diccionario contextual de expresiones fraseológicas]. Líbano: Maktabat Libnān Naširūn [DCEF].

Taymūr, A. (1956). Al-amtāal al-'àmmiyya, mašrūḥa wa-murattaba 'alà al-ḥarf al-awwal min al-matal [Los refranes coloquiales]. El Cairo: Mațābi 'Dār al-Kitāb al- 'Arabī bi-Mișr.

- (I980). Introducción al estudio de las expresiones fijas. Frankfurt a. M./Bern: Peter D. Lang. 